\title{
Japan's science spending climbs again
}

Tokyo. Despite facing the tightest budget in almost a decade, the Japanese government has agreed to a substantial increase in its spending on science and technology for the fiscal year 1997, beginning on 1 April.

Overall, science and technology expenditure across all ministries will grow by 11.9 per cent, according to figures released by the Ministry of Finance. This keeps the country on target to meet a promise made last June to boost spending on research by 50 per cent over the next five years.

The life sciences have done particularly well, with the Science and Technology Agency (STA) seeing its budgets for research in this area grow by 22.9 per cent. The Ministry of Education, Science, Sports and Culture, which now accounts for 42.9 per cent of all government spending on science and technology, will have an additional $¥ 10.4$ billion (US\$89 million) of research grants to allocate in the year ahead.

In contrast, total government spending will rise by only 3 per cent to $¥ 77,390$ billion - the smallest increase for nine years. The figures were approved by the cabinet last month but still have to be formally accepted by the Diet, Japan's parliament. Public finances are under severe pressure because of economic recession, the need to bail out some banks, as well as housing and loan corporations, and the rapidly growing number of elderly people in the population.

The government is determined to reduce borrowing by raising taxes and controlling public expenditure. But, despite the austere financial climate, all Japan's science-related ministries have managed to win increases in their budgets of between 4 and 12 per cent.

The increases follow the launch of Japan's new five-year plan for science and technology, announced last June. Under the plan, the government has agreed to increase spending on science and technology to $¥ 17,000$ billion over the next five years. Despite deteriorating government finances, the Ministry of Finance is backing the plan. "Support for scientific research is essential for Japan's economic future," says one ministry official.

The ambitious plan originated following lobbying by a small group of comparatively young and powerful politicians from various political parties (see Nature 378, 227; 1995). Its acceptance by the government represents agreement that such increases are needed to build new creative industries and improve the quality of life.

Several ambitious new projects in the life sciences have won financial backing. The STA will set up a brain science research institute at the Institute of Physical and Chemical Research (RIKEN) in October (see Nature 383, 7; 1996), in addition to receiving $¥ 1.9$ billion for protein structure analysis, which received only $¥ 0.2$ million this year.

The research and development budget for new industries at Japan's powerful Ministry of Trade and Industry (MITI) has more than doubled and includes $¥ 7.1$ billion for special funding for national research institutes (up 108 per cent) of which $¥ 2.2$ billion will be allo-

Total budget Space

Spring-8

Human genome

STA fellowships

Brain

cated by competitive tender under a new initiative. MITI also gets a new budget for interministry research projects conducted at national research institutes. These funds will into genetics, brain science, earthquake and biotechnology research. There are substantially more funds available at many ministries for postdoctoral fellowships and other schemes to encourage young researchers.

Richard Nathan

Highlights of Japan's budget for S\&T 1997

(in billion yen: US\$1 $¥ ¥ 114$ )

Science and Technology Agency (STA)

734.5 $+6.0 \%$

General R\&D budget

Protein structure analysis

$\mathbf{5 7 1 . 4}+\mathbf{8} . \mathbf{0} \%$

$180.6+1.5 \%$

$19.2+15.4 \%$

$2.9+17.5 \%$

$1.9+688.0 \%$

$3.1+23.3 \%$

$9.9+296.0 \%$

Ministry of Trade and Industry (MITI)

Total R\&D budget

Agency for Industrial Science \& Technology

New industry R\&D

Industrial scientific technology

Joint ministry research projects

Human Frontier Programme*

* includes 2.4 billion yen from STA

421.3

162.0

26.8

28.0

3.4

4.0

Ministry of Education, Science, Sports and Culture

Grants in Aid for Scientific research

Japan Society for Promotion of Science (postdoctoral fellowships)

Joint research with industry

Academic information network

Centre of excellence (COE) programme

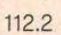

\section{France says goodbye to the fast-breeder as Superphénix}

Paris. Almost four decades of effort by France to build fast-breeder reactors to produce electricity commercially from plutonium came to an end on Christmas eve, when its 1,250-MW Superphénix prototype power plant in Creys-Malville was shut down. The plant will be converted into a research reactor intended to burn up plutonium from waste and dismantled weapons, as well as actinide wastes (see Nature 365, 381; 1993).

Ironically, although 1996 was the last year in which Superphénix operated as a commercial prototype, it was the first year in which the troubled reactor operated smoothly. The 3 billion kilowatt-hours of electricity it generated equalled the total produced from its entry into service in 1986 until the end of 1995 - over this period, technical problems meant that it operated for a total of only ten months.
Now, 72 of the 220 fuel elements in the core will be replaced with stainless-steel dummies to reduce the reactor's capacity to produce plutonium. At the same time, three experimental fuel elements will be placed in the core in preparation for future research. Two will contain plutonium configured for experiments to boost the reactor's capacity to incinerate plutonium. The other will contain $2 \mathrm{~kg}$ of the highly radioactive actinide, neptunium. The reactor will begin to incinerate plutonium only around 2003, when it will be equipped with a core lacking a uranium blanket.

The conversion marks the end of the last programme in Europe to develop a generation of fast breeders for electricity production. A project to build a European Fast Reactor has also been abandoned following the withdrawal of the United Kingdom and Germany in 1992 (see Nature
$360,93 \& 703 ; 1992)$. Only Japan is now actively pursuing the technology (see Nature 379, 196; 1996).

But the French government's decision in 1994 to reincarnate Superphénix as a research reactor has not dampened the controversy surrounding it. At the time, the decision was widely viewed as a political solution to the need to satisfy France's partners in NERSA, the consortium of French, German and Italian utilities that built Superphénix in the 1970s at a cost of FFr27.7 billion (US\$5.2 billion) (see Nature 368, 281; 1994).

The French government has since agreed to pay its partners in the project an estimated FFr1 billion annually - in the form of electricity - to compensate for loss of income following the conversion. To these costs must be added that of the planned research programme (FFr500 


\section{'Misconduct' dispute raises fears of litigation}

San Diego. A legal dispute with potentially far-reaching implications for the way universities investigate scientific misconduct cases has been generated by the conclusion of a report from Baylor College of Medicine in Houston, Texas, that one of its researchers published data that had been fabricated.

The dispute has raised the question of whether universities should be immune from certain types of civil lawsuit arising from investigations of research misconduct carried out as required by National Institutes of Health (NIH) regulations.

The dispute centres on Kimon J. Angelides, a neurobiologist who was fired by Baylor in early 1995 after officials concluded that he had falsified research results described in five published papers and in documents used in applications for NIH grants (see Nature 383, 107; 1996).

Angelides subsequently moved to the University of Durham in England. He filed a civil lawsuit against Baylor, the scientists who had accused him of improprieties, and members of various ad hoc committees at Baylor that ruled that he had committed scientific misconduct.

The civil lawsuit is for wrongful termination, breach of contract, defamation and other actions. These include an allegation of 'blacklisting', a charge associated with the fact that Baylor reported Angelides' alleged offences to the NIH's Office of Research Integrity (ORI), the body that investigates allegations of research misconduct made against scientists receiving NIH funds.

This lawsuit is before a federal appeals court, where Angelides, Baylor and other interested parties are arguing about whether a university should be immune from certain civil lawsuits when investigating misconduct.

\section{takes on new role}

million annually), the reactor's annual running costs (around FFr1 billion ) and the FFr1.25-billion cost of a new core. The French national audit commission recently estimated that the reactor will have cost a total of FFr60 billion by 2000 .

But continuing to operate the reactor is considered to be cheaper than shutting it down. A shutdown would entail the government paying as much as FFr18 billion in compensation to NERSA as a lump sum, as well as the costs of decommissioning.

Whatever the outcome of the research, few expect France to invest in the short term in the many fast breeders that would be needed in practice to eliminate the large stocks of plutonium. Superphénix, which will eventually shut down for good around 2015, seems likely to be one of the last of a dying breed.

Declan Butler
In addition to the civil litigation, federal prosecutors in Houston have opened a criminal inquiry into Angelides' research activities. This raises the possibility that he could be indicted for defrauding the NIH of research funds.

Such criminal investigations are rare, with only one scientist in recent years having been convicted of a crime related to research misconduct.

In the civil case, the federal requirement that a university that receives NIH grants should monitor its scientists, investigate allegations of misconduct and report the conclusions is clashing with an accused scientist's right to due process.

Angelides denies any research misconduct, blaming others for any discrepancies in his reported results. His attorneys argue that he should be able to sue his accusers for damages in a Texas state court, where his civil lawsuit was filed.

But Baylor's attorneys reply that the university is immune from such state court civil action as it is acting for a federal agency, the NIH. They also argue that if the verdict of a civil lawsuit is to be based on the propriety of a university probe of a scientist, the case should be heard in a federal district court, not a state court.

Such issues have already attracted much interest from the Association of American Medical Colleges (AAMC), as well as the ORI, both of which have filed briefs supporting Baylor's position.

Chris B. Pascal, acting director of the ORI, says his agency fears that if Angelides' method of suing is upheld, an already difficult process - the scientific review of misconduct charges at the university level will be significantly damaged, if not destroyed.

Angelides' lawsuit against Baylor threatens the "partnership" between the NIH and research institutions, says Pascal. "This is a big issue for us," he adds. "If an institution and its committees of scientists are held liable for reporting to ORI, who would write a report and put their name on it? They wouldn't do it any more."

Similarly Joseph A. Keyes Jr, general counsel to the AAMC, says his members believe that state court lawsuits filed by scientists whose research has been challenged by their peers would have a chilling effect on the ability of universities to fulfil their obligations to funding agencies to monitor the conduct of research.

"Faculty members and [other] individuals called to serve on investigating committees fear being tied up in endless litigation," says Keyes, whose organization represents 400 universities and medical schools and 90 professional societies.

Such arguments are being made in legal briefs before the US Court of Appeals for the Fifth Circuit in New Orleans. A decision on the immunity issue is expected in a few months, and could have broad implications for scientific misconduct cases elsewhere in the United States.

Meanwhile, the trial in Angelides' civil lawsuit has been postponed until August, largely because of the criminal probe of his activities. The existence of the criminal inquiry surfaced last month during a hearing on the civil lawsuit.

Angelides had flown from the United Kingdom to Houston to be questioned by Baylor's attorneys in a deposition. But,

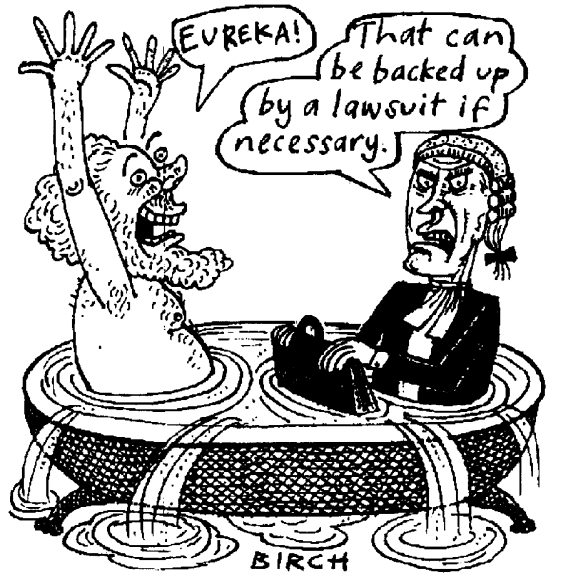

during a brief hearing with the attorneys, Angelides' attorney argued that the pending criminal probe might use his sworn deposition testimony against him, and invoked his Fifth Amendment privilege against selfincrimination.

David H. Peck, the assistant US attorney in Houston who is conducting the inquiry into Angelides' actions, declines to comment on the federal probe. Court records indicate that federal authorities are expected to make a decision on whether to file criminal charges within a month or so.

Angelides declines to comment on his situation. But Rusty Hardin, his criminal attorney in Houston, argues that, for a criminal violation, "someone must conclude that he [Angelides] knowingly submitted false information" to the NIH, which he "unequivocally" did not.

"There is no issue [that] some wrong data was submitted," says Hardin. "The question is: did he know it was wrong when he submitted it? I am satisfied there is no criminal violation."

Pascal at ORI declines to comment on how the criminal inquiry may affect his agency's investigation of Angelides, which started in spring 1995. The ORI cooperates with federal prosecutors when they conduct criminal inquiries, he says, and may delay or complete its investigation, depending on what the federal prosecutors may want.

Rex Dalton 